\title{
Technical Note: Persistence and yield of ladino white clover in southeastern Louisiana
}

\author{
MARK K. JOHNSON
}

The author is professor of wildlife, School of Forestry, Wildlife, and Fisheries, Louisiana Agricultural Experiment Station, LSU Agricultural Center, Baton Rouge 70803.

\begin{abstract}
Ladino white clover (Trifolium repens $\mathbf{L}$.) is usually reestablished annually for cool-season and early warm-season pasture improvement. Careful pasture management during summer can encourage persistence of stolons so that renovation and reseeding may not be needed for subsequent grazing. Ladino white clover might be manageable for both cool- and warm-season grazing if grass competition is controlled. Both cool- and warm-season yields of persisting ladino white clover exceeded that of new plantings by an average $( \pm S E)$ of $180 \pm 41 \%$. Winter yields of persisting swards averaged $5,250 \pm 350 \mathrm{~kg} / \mathrm{ha}$ while those of new plantings were only $1,379 \pm 182 \mathrm{~kg} / \mathrm{ha}$. Average standing crop of persisting and new plantings was $3,497 \pm 724$ and $2,500 \pm 378 \mathrm{~kg} / \mathrm{ha}$, respectively, from June through September. Suppression of warm-season competition leading to ladino white clover persistence may produce economic and soil conservation advantages. The greatest advantage of managing for persistence appeared to be increased forage for winter grazing.
\end{abstract}

\section{Key Words: legume, pasture renovation, Trifolium repens}

Most covers used for cool-season pastures in the southeastern United States are annuals that flower in spring and die by early summer. Subsequent pasture production requires renovation to release competition and promote seedling survival (Johnson et al. 1987). Because of the humid environment and soft-seeded nature of many commonly available clovers, plants may not volunteer well due to early germination of seeds when competition from warm-season grasses is high. Therefore, additional seed is usually used with annual renovation to ensure reasonable production. A long-term result of this annual soil disturbance is soil erosion with subsequent lowering of pasture fertility.

White clovers may persist longer into summer months than other species (Baltensperger et al. 1984). I observed some swards of ladino white clover (Trifolium repens L.) that persisted all summer, providing good winter production the second year without renovation. These pastures were initially planted after intensive seed-bed preparation ( 5 diskings at 2-week intervals) to eliminate warm-season, sod-forming grasses. This observation was significant because white clover seedling vigor is low so that new plantings often do not produce adequate yields for grazing until spring. Producers often use clover species with higher seedling vigor when winter grazing is their primary objective. These species

\footnotetext{
Funding was provided by the Louisiana Agricultural Experiment Station under project LABO 2516. Sacramento Valley Milling, Inc., provided seed for use in the experiment. The author wishes to thank B.R. Jones, B.G. Jones, and G.W. Berger for use of their properties.

Manuscript accepted 30 Apr. 1993.
}

usually die earlier and produce less opportunity for early summer grazing. Therefore, I conducted experiments with ladino white clover to determine if summer persistence could be consistently achieved, to estimate warm-season grazing potentials, and to compare winter yields of new plantings with persisting swards.

\section{Materials and Methods}

\section{Study Areas}

Field studies were conducted on the Blairstown and Shades Plantations in East Feliciana Parish near Clinton, La. Soils on the study areas are Tangi (Typic Fragiudults)-Oliver (Aquic Fragiudalfs) and Tangi-Lytle (Typic Paleudults) silt loams of the Loessil Hills Association. These are acid, gently sloping, and moderately well-drained upland soils of low fertility. Average $\mathrm{pH}$ of the surface soil at plot locations was 5.1, and levels of $\mathrm{P}_{2} \mathrm{O}_{5}$ and $\mathrm{K}_{2} \mathrm{O}$ averaged 5 and $23 \mathrm{ppm}$, respectively.

\section{Plot Preparation}

During summer 1987,25 plots ( 0.5 ha each) were prepared for fall planting by disking 5 times at 2-week intervals to kill sodforming grasses (the first disking was done on 15 July). Dolomitic lime was added at 4,500 kg/ha (Peevy 1972). During late September, ladino white clover (var. Osceola) was seeded at $20 \mathrm{~kg} / \mathrm{ha}$ with $300 \mathrm{~kg} / \mathrm{ha}$ of 8-24-24 fertilizer and cultipacked to ensure soil contact. Fourteen of the plots were on the Blairstown Plantation and 11 were at the Shades Plantation.

During summer 1988, 5 additional plots were prepared on each property, as described above, and fertilized and seeded in September so that yields could be compared between new plantings and swards persisting into the second year. All plots planted in 1987 were mown above the clover in August 1988 to reduce weed competition and fertilized as before. Livestock were excluded throughout the study, but grazing by white-tailed deer (Odocoileus virginianus) kept all herbage at ground level.

In fall 1988, 3 exclosures ( 1 by $1 \mathrm{~m}$ ) were randomly placed on each of the 35 plots to eliminate use by white-tailed deer, which were abundant at both sites. Herbage was clipped in a single 20 by $20-\mathrm{cm}$ quadrat placed in each exclosure during late February 1989 to compare peak winter standing crops. Exclosures were moved about $3 \mathrm{~m}$ and sampled again in May to compare spring standing crops. These herbage clippings represented regrowth following grazing by deer. The process was repeated monthly thereafter to evaluate summer production and persistence. All herbage clippings were placed in paper bags and oven dried at $60^{\circ} \mathrm{C}$ for 24 hours before weighing.

Data collected from the 3 quadrats per plot were averaged to give a mean yield per sampling date and plot. Means between 
treatments were statistically compared using normal variates rather than the Student's $t$ distribution (Mood et al. 1974). Otherwise, statistical comparisons between means were calculated in a manner similar to procedures used for Student's $t$ tests. Data presented are means and standard errors of the means.

\section{Results and Discussion}

Although the last measurements were made in 1989, all plots persisted through spring of 1991 . There were no significant differences in mean ladino white clover standing crops between Blairstown and Shades study locations for persisting swards, for new plantings, or for any sampling date $(P>0.2)$. Therefore, mean standing crop estimates were averaged across locations. Persisting swards produced significantly more forage $(P<0.05)$ than new plantings, especially considering winter standing crops (Table 1).

Table 1. Mean ( \pm SE) oven-dry yields of Osceola ladino white clover from February to September 1989 in East Feliciana Parish, Louisiana, averaged across study locations. Persisting plantings $(n=25)$ were seeded in September 1987 and new plantings $(n=10)$ were seeded in September 1988.

\begin{tabular}{llc}
\hline \hline Month of Sampling & New Planting & Persisting Planting \\
\hline & $\cdots \ldots \ldots-\ldots(\mathrm{kg} / \mathrm{ha})$ & $\ldots \ldots \ldots$ \\
February & $1379 \pm 182$ & $5250 \pm 350$ \\
May & $4963 \pm 578$ & $7665 \pm 698$ \\
June & $3394 \pm 311$ & $4761 \pm 403$ \\
July & $1954 \pm 199$ & $2416 \pm 356$ \\
August & $2859 \pm 408$ & $4729 \pm 628$ \\
September & $1795 \pm 310$ & $2080 \pm 619$ \\
\hline
\end{tabular}

In February, persisting swards produced about 3.8 times more forage than new plantings. Production peaked in spring with more than $3,000 \mathrm{~kg} / \mathrm{ha}$ and more than $2,000 \mathrm{~kg} / \mathrm{ha}$ for persisting and new swards, respectively. Summer production of persisting swards ranged from about $1,000 \mathrm{~kg} /$ ha to more than $2,000 \mathrm{~kg} / \mathrm{ha}$ for persisting swards. Although summer standing crops were consistently higher for persisting swards compared to new plantings, they were not significantly different for July and September $(P>0.2)$, the driest months. For the months of June and August, persisting swards produced about $50 \%$ more ladino white clover than the newer plantings $(P<0.1)$. Apparently, the longer-established stolons were able to take better advantage of the limited moisture.

Although a variety of warm-season annual legumes are adapted to the southeastern United States, few warm-season perennial legumes are available, and there is a great need for persitent perennial species (Ball et al. 1991). The unexpectedly high second-year summer yields of persisting ladino white clover could be of significant importance. Ladino white clover might be used for both cool-and warm-season grazing under appropriate management, and this could represent significant savings to livestock producers from both economic and soil conservation aspects. Regardless of summer grazing potentials, the value of second-year winter clover production provides a substantial economic advantage considering elimination of costs for seed and disking, and the dramatically increased forage production. Based on the cost for new plantings compared to maintenance of persisting swards $(\approx \$ 566 /$ ha vs. $\$ 134 /$ ha, respectively, Johnson and Dancak 1993), the cost of ladino white clover for winter grazing was $\$ 0.41 / \mathrm{kg}$ for new plantings and about $\$ 0.03 / \mathrm{kg}$ for second-year persisting swards. Although this represents a dramatic difference, an accurate comparison for any individual producer would require consideration for lost opportunity if warm-season use was deferred, and any additional costs required to manage for persistence of the ladino white clover.

\section{Literature Cited}

Ball, D.M., C.S. Hoveland, and G.D. Lacefield. 1991. Warm season legumes, p. 50-55. In: Ball, Hoveland and Lacefield (eds.), Southern Forages. Potash and Phosphate Institute and Foundation for Agronomic Research. Atlanta, Ga.

Baltensperger, D.D., C.E. Dean, E.S. Horner, L.S. Dunavin, W.R. Ocumpaugh, and P. Mislevy. 1984. Osceola white clover. Agr. Exp. Sta., Inst. Food and Agr. Sci. Circ. S-311, Univ. Florida, Gainesville.

Johnson, M.K., B.S. Delany, S.P. Lynch, J.A. Zeno, S.R. Schultz, T.W. Keegan, and B.D. Nelson. 1987. Effects of cool-season agronomic forages on white-tailed deer. Wildl. Soc. Bull. 15:330-339.

Johnson, M.K., and K.D. Dancak. 1993. Effects of food plots on whitetailed deer in Kisatchie National Forest. J. Range Manage. 46:1 10-1 14.

Mood, A.M., F.A. Graybill, and D.C. Boes. 1974. Introduction to the theory of statistics. 3rd ed. McGraw-Hill, N.Y.

Peevy, W.J. 1972. Soil test results and their use in making fertilizer and lime recommendations. I.ouisiana Agr. Exp. Sta. Bull. 660. 